\title{
Anatomy of the reproductive tract of the female African elephant (Loxodonta africana) with reference to development of techniques for artificial breeding
}

\author{
J. M. E. Balke, W. J. Boever, M. R. Ellersieck*, U. S. Seal $\dagger$ and \\ D. A. Smith $\ddagger$ \\ St. Louis Zoological Park, Forest Park, St. Louis, Missouri 63110, U.S.A.; *University of \\ Missouri, Columbia, Missouri 65211, U.S.A.; †Veterans Administration Hospital, Minneapolis, \\ Minnesota 55417, U.S.A.; and $\ddagger$ University of Zimbabwe, Harare, Zimbabwe
}

\begin{abstract}
Summary. Complete reproductive tracts of 30 female African elephants (5-53 years), obtained during a population reduction procedure, were examined. The reproductive tracts were palpated in situ via the urogenital canal. A plastic speculum $(1.3 \times 170 \mathrm{~cm})$ was introduced into the canal and dye was injected to simulate the procedure for artificial insemination. The lengths of reproductive tracts (from the vulva to the ovary) ranged from 120 to $358 \mathrm{~cm}$. The length increased with the size and age of the animal. There was a membranous constriction (hymen) with an orifice, $<2 \mathrm{~cm}$ in diameter, between the urogenital canal and the vagina, in 4 primigravid and in all 13 nulliparous elephants. The vaginal orifice of 13 multiparous elephants consisted of ragged folds of mucous membrane surrounding a single opening, $5-19 \mathrm{~cm}$ in diameter. The ages at first conception of 4 pregnant elephants with intact hymenal membranes were $10,12,13$ and 14 years. The hymen was not penetrated as a result of intromission and therefore the site of ejaculation would have been in the urogenital canal of the 4 primigravid elephants.
\end{abstract}

Keywords: anatomy; artificial breeding; elephant; female

\section{Introduction}

Elephant populations in captivity have traditionally been maintained by collecting replacement animals from the wild. Reproduction within zoos has been limited by the scarcity of intact mature male elephants in captivity. Males are difficult and costly to exhibit safely or to transport for breeding purposes. Zoos' researchers have been investigating the reproductive biology and artificial breeding techniques in elephants to assist the development of self-sustaining captive populations (Nevill et al., 1976; Ruedi \& Kuepfer, 1981; Schmidt, 1982; Price et al., 1986; Balke et al., 1987; Plotka et al., 1988). Hormone values have been measured for oestrous cycle determination and semen has been collected and used to inseminate elephant cows artificially. As yet, no offspring have been produced by artificial means.

Reproductive, anatomical and endocrine data have been collected from wild elephant herds culled during population control programmes in Africa (Buss \& Smith, 1966; Laws, 1967; Sherry, 1975). This information has been used in designing field management strategies. The elephant 
control programme in Zimbabwe's Gonarezhou National Park in 1986 provided an opportunity for integrating studies of the reproductive tract of female elephants in the field and in captivity. This paper reports a study of the anatomy of the reproductive tract of females in the hope that it would provide better understanding of the anatomical structures involved for the development of artificial insemination (AI) techniques in elephants.

\section{Materials and Methods}

Elephants were removed in July and August 1986, during a population control programme in the Lundi Valley of the Gonarezhou National Park. Family units (females and juveniles, excluding young weaned calves) were shot with heavy calibre rifles. The anatomy study was carried out in co-operation with researchers of the Department of National Parks and Wildlife.

One or two female elephants were selected each day for the anatomy study. Their udders were examined for the presence of milk. A gloved hand was inserted into the urogenital canal (vestibule) and the structures in the proximal canal were palpated. A round flexible plastic speculum measuring $1.3 \mathrm{~cm}$ in diameter and $170 \mathrm{~cm}$ long was inserted into the urogenital canal and advanced as far as possible into the reproductive tract. In one half of the animals the tube was passed blindly and in the others the insertion was assisted by manual palpation. Then $30 \mathrm{ml}$ methylene blue dye (Ricca Chem., Arlington, TX, U.S.A.) were injected through a tube, $1.5 \mathrm{~mm}$ in diameter, within the speculum. The time allowed for the palpation and dye injection procedure was limited to $0.5-2 \mathrm{~min}$.

Dissections were completed for the reproductive tracts of 30 female elephants. The ovaries were detached from each side and the entire tract was removed through the pelvic canal. Large fetuses were removed from the uterus while in the abdomen. The lengths of the reproductive tracts were measured immediately. Placental scars in each nonpregnant uterus were counted (Laws, 1967) and the number, size and weight of corpora lutea in each ovary were determined. The National Parks Department researchers measured the shoulder heights, collected the jaws to use for ageing and weighed and measured the fetuses. The ages of the elephants were estimated using a modification of the tooth ageing technique described by Lang (1980).

Measurements of the urogenital canal, vagina, and cervix of all elephants and all segments of the reproductive tract of the non-pregnant elephants were related to shoulder height and age by linear regression techniques. The fetal age was calculated from the fetal weight using the formula derived by Craig (1984), i.e. $t=106 w^{1 / 3}+138$, where $t=$ the age of the fetus in days and $w=$ the fetal mass in $\mathrm{kg}$. The fetal age was subtracted from the maternal age to give the age at conception.

\section{PREGNANT}

Table 1. Reproductive anatomical data collected from 11 pregnant African elephants

\begin{tabular}{|c|c|c|c|c|c|c|c|c|c|}
\hline $\begin{array}{c}\text { Shoulder } \\
\text { height } \\
(\mathrm{cm})\end{array}$ & $\begin{array}{c}\text { Age } \\
\text { (years) }\end{array}$ & $\begin{array}{c}\text { Fetal } \\
\text { weight } \\
\text { (g) }\end{array}$ & $\begin{array}{l}\text { Urogenital } \\
\text { canal } \\
\text { length } \\
(\mathrm{cm})\end{array}$ & $\begin{array}{l}\text { Vaginal } \\
\text { orifice } \\
\text { width } \\
(\mathrm{cm})\end{array}$ & $\begin{array}{l}\text { Vaginal } \\
\text { length } \\
(\mathrm{cm})\end{array}$ & $\begin{array}{c}\text { Cervix } \\
\text { length } \\
(\mathrm{cm})\end{array}$ & $\begin{array}{c}\text { Uterine } \\
\text { body } \\
\text { length } \\
(\mathrm{cm})\end{array}$ & $\begin{array}{c}\text { Maximum } \\
\text { uterine } \\
\text { horn } \\
\text { length } \\
\text { (cm) }\end{array}$ & $\begin{array}{c}\text { Total } \\
\text { reproductive } \\
\text { tract } \\
\text { length } \\
\text { (cm) }\end{array}$ \\
\hline 243 & 25 & - & 128 & 11 & 37 & 7 & 6 & 166 & 344 \\
\hline 236 & 20 & 1600 & 90 & 8 & 33 & 8 & 12 & 113 & 256 \\
\hline 232 & 49 & - & 110 & 17 & 62 & 7 & 5 & 174 & 358 \\
\hline 229 & 14 & - & 104 & 17 & 48 & 9 & 18 & 164 & 343 \\
\hline $229^{*}$ & 14 & 7200 & 92 & $3.4 t$ & 26 & 9 & 24 & 113 & 264 \\
\hline $226^{*}$ & 11 & 94000 & 88 & $4.5+$ & 30 & 9 & 11 & 136 & 274 \\
\hline 222 & 18 & - & 98 & 19 & 43 & 10 & 14 & 151 & 316 \\
\hline $222^{*}$ & 14 & 2000 & 84 & $3.0 \dagger$ & 30 & 5 & 17 & 118 & 254 \\
\hline 221 & 18 & 2 & 88 & 5 & 23 & 5 & 22 & 81 & 219 \\
\hline $221^{*}$ & 13 & 625 & 98 & $2.9 \dagger$ & 32 & 6 & 17 & 89 & 242 \\
\hline 219 & 13 & - & 104 & 6 & 23 & 5 & 17 & 112 & 261 \\
\hline \multicolumn{10}{|l|}{ Mean: } \\
\hline $227 \cdot 27$ & 18.98 & & $98 \cdot 55$ & & $35 \cdot 18$ & $7 \cdot 27$ & $14 \cdot 82$ & $128 \cdot 82$ & 284.64 \\
\hline \\
\hline $7 \cdot 46$ & $10 \cdot 76$ & & 12.68 & & $11 \cdot 82$ & 1.85 & 5.98 & $31 \cdot 59$ & $47 \cdot 20$ \\
\hline
\end{tabular}

*Primigravid.

†Includes width across 3 openings. 


\section{Results}

The longitudinal dimensions of the reproductive tracts and the heights and ages of the elephants are given in Tables 1 and 2. The lengths of various segments, of the tracts of non-pregnant elephants increased with the increasing size and age of the elephant. The regression coefficients with age were significant for the total tract, urogenital canal and the uterine horn lengths (Table 2). The regression coefficients with shoulder height were significant for the lengths of the above segments as well as for the lengths of the cervix and uterine body. The anatomical structure and divisions of the female African elephant reproductive tract were similar to those observed in three nulliparous Asian elephants (Balke et al., 1988). The urogenital canal was a long, narrow tube equal in length to about one half of the entire length of the reproductive tract of the non-pregnant elephants.

\section{NoN -pregniant}

Table 2. Reproductive anatomical data collected from 19 non-pregnant African elephants

\begin{tabular}{|c|c|c|c|c|c|c|c|c|c|c|}
\hline $\begin{array}{l}\text { Shoulder } \\
\text { height } \\
\text { (cm) }\end{array}$ & $\begin{array}{l}\text { Age } \\
\text { (years) }\end{array}$ & Status $†$ & $\begin{array}{l}\text { No of } \\
\text { placental } \\
\text { scars }\end{array}$ & $\begin{array}{c}\text { Urogenital } \\
\text { canal } \\
\text { length } \\
\text { (cm) }\end{array}$ & $\begin{array}{l}\text { Vagina } \\
\text { orifice } \\
\text { width } \\
(\mathrm{cm})\end{array}$ & $\begin{array}{l}\text { Vagina } \\
\text { length } \\
(\mathrm{cm})\end{array}$ & $\begin{array}{l}\text { Cervix } \\
\text { length } \\
(\mathrm{cm})\end{array}$ & $\begin{array}{l}\text { Uterine } \\
\text { body } \\
\text { length } \\
(\mathrm{cm})\end{array}$ & $\begin{array}{l}\text { Maximum } \\
\text { uterine } \\
\text { horn } \\
\text { length } \\
\text { (cm) }\end{array}$ & $\begin{array}{l}\text { Total } \\
\text { length } \\
(\mathrm{cm})\end{array}$ \\
\hline 252 & 45 & Mature & 8 & 122 & 11 & 38 & 6 & 6 & 73 & 245 \\
\hline 246 & 25 & Mature & 4 & 110 & 17 & 51 & 9 & 35 & 76 & 281 \\
\hline 245 & - & Mature & 8 & 104 & 18 & 31 & 8 & 26 & 74 & 243 \\
\hline 240 & 53 & Mature & 2 & 105 & 7 & 15 & 8 & 12 & 68 & 208 \\
\hline 236 & 14 & Mature & 3 & 83 & 5 & 17 & 5 & 15 & - & - \\
\hline 232 & 23 & Mature & - & 90 & 8 & 9 & 5 & 8 & 70 & 182 \\
\hline 211 & 9 & Null. & 0 & 98 & $1 \cdot 4 t$ & 21 & 4 & 3 & 46 & 172 \\
\hline 206 & 10 & Null. & 0 & 88 & $3.0 \ddagger$ & 17 & 7 & 3 & 45 & 160 \\
\hline 203 & 10 & Null. & 0 & 118 & $3 \cdot 0 \div$ & 17 & 10 & 13 & 72 & 230 \\
\hline 200 & 9 & Null. & 0 & 80 & $2 \cdot 8 \ddagger$ & 21 & 5 & 6 & 38 & 150 \\
\hline 200 & 10 & Null. & 0 & 88 & $1.8 \pm$ & 16 & 4 & 5 & 32 & 145 \\
\hline 200 & 7 & Null. & 0 & 82 & $1.4 f$ & 21 & 7 & 6 & 45 & 161 \\
\hline 198 & 9 & Null. & 0 & 94 & $2 \cdot 3 \ddagger$ & 25 & 8 & 12 & 44 & 183 \\
\hline 198 & 11 & Null. & 0 & 86 & $2 \cdot 1 \ddagger$ & 20 & 6 & 14 & 47 & 173 \\
\hline 196 & 6 & Null. & 0 & 84 & $2 \cdot 0 \ddagger$ & 26 & 5 & 5 & 73 & 193 \\
\hline 188 & 6 & Null. & 0 & 76 & $1.9 \ddagger$ & 23 & 6 & 12 & 52 & 169 \\
\hline 187 & 5 & Null. & 0 & 68 & 1.87 & 23 & 4 & 4 & 35 & 134 \\
\hline 171 & 5 & Null. & 0 & 80 & $2 \cdot 0+$ & 20 & 2 & 8 & 35 & 145 \\
\hline 165 & 6 & Null. & 0 & 68 & $3 \cdot 1+$ & 18 & 5 & 5 & 24 & 120 \\
\hline \multicolumn{11}{|l|}{ Mean: } \\
\hline $209 \cdot 6$ & $14 \cdot 64$ & & & $90 \cdot 74$ & & $22 \cdot 58$ & $6 \cdot 0$ & $10 \cdot 42$ & $52 \cdot 72$ & $183 \cdot 0$ \\
\hline \multicolumn{11}{|l|}{ s.d. } \\
\hline 25.54 & 13.69 & & & $15 \cdot 34$ & & $9 \cdot 29$ & $2 \cdot 0$ & $8 \cdot 18$ & $17 \cdot 31$ & 43.22 \\
\hline \multicolumn{11}{|c|}{ Regression with age } \\
\hline \multirow{2}{*}{\multicolumn{4}{|c|}{$\begin{array}{l}\text { Regression coefficient } \\
\mathrm{R}^{2} \text { coefficient of determination }\end{array}$}} & $0 \cdot 75^{*}$ & & $0 \cdot 05$ & $0 \cdot 11$ & $0 \cdot 14$ & $0 \cdot 36^{*}$ & $1 \cdot 8^{*}$ \\
\hline & & & & 0.45 & & 0.15 & 0.05 & 0.07 & 0.716 & 0.37 \\
\hline \multicolumn{11}{|c|}{ Regression with shoulder height } \\
\hline \multicolumn{4}{|c|}{ Regression coefficient } & $0 \cdot 49^{*}$ & & $0 \cdot 17$ & $0 \cdot 04^{*}$ & $0 \cdot 17^{*}$ & $0 \cdot 54^{*}$ & $1 \cdot 4^{*}$ \\
\hline \multicolumn{4}{|c|}{$\mathrm{R}^{2}$ coefficient of determination } & 0.62 & & $0 \cdot 21$ & 0.25 & $0 \cdot 26$ & 0.62 & 0.68 \\
\hline
\end{tabular}

$†$ Mature $=$ mature and lactating; Null. = nulliparous.

$\ddagger$ Includes width across 3 openings.

${ }^{*} P<0.05$.

Palpation of the urogenital canal was possible in all elephants. The structures palpated in 19 of the elephants included a distinct wide vaginal orifice (the opening from the urogenital canal into the vagina), several folds of mucous membrane or simply the caudal pelvic brim. A small vaginal 


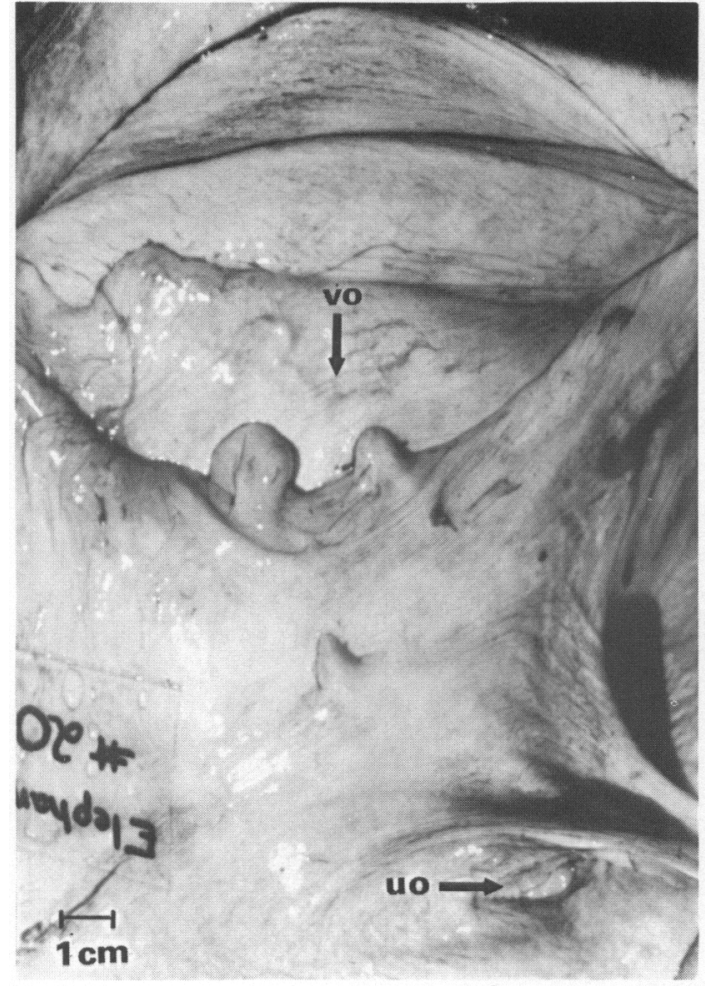

Fig. 1

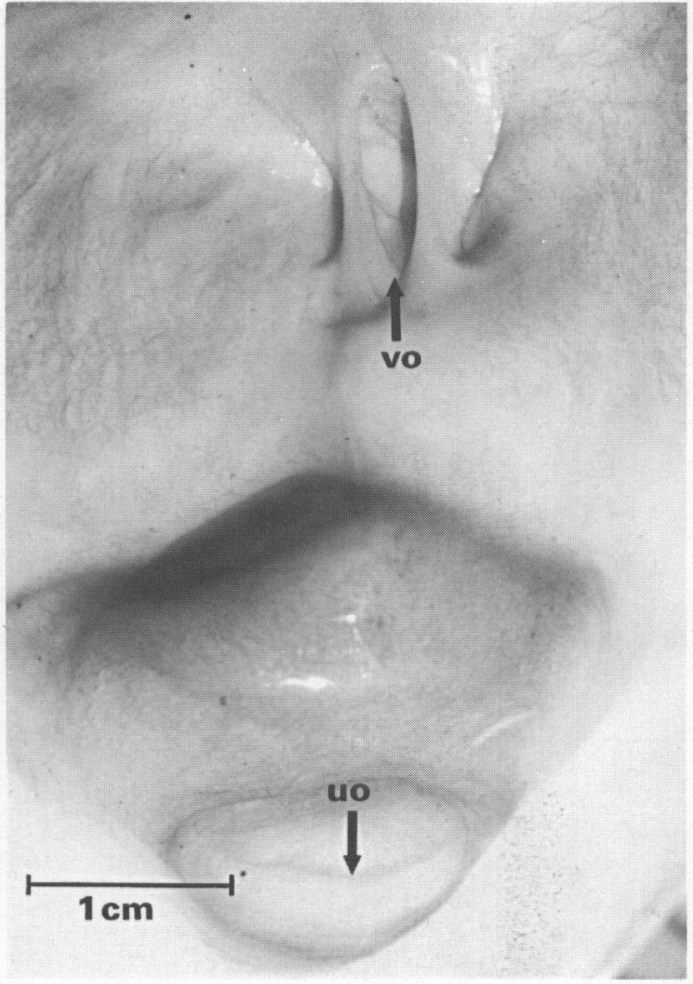

Fig. 2

Fig. 1. Vaginal orifice of a mature female (view from the urogenital canal): vo, vaginal orifice; uo, urethral orifice.

Fig. 2. Intact hymen (view from the urogenital canal): vo, vaginal orifice; uo, urethral orifice.
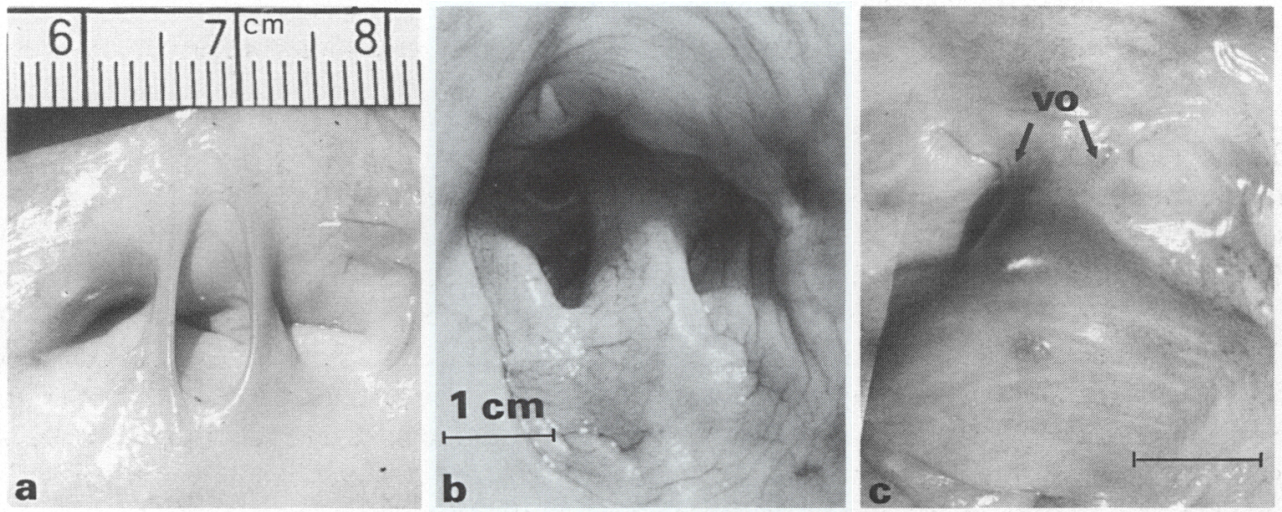

Fig. 3. Variations of the hymen (view from the urogenital canal). (a) Most common configuration. (b) Hymen with three holes and a single vertical band of tissue across the distal side of the opening. (c) Hymen with a solid central area, $0.5 \mathrm{~cm}$ across, with two tiny patent vaginal openings (vo), $<2 \mathrm{~mm}$, on either side and 2 small blind canals beside them. 

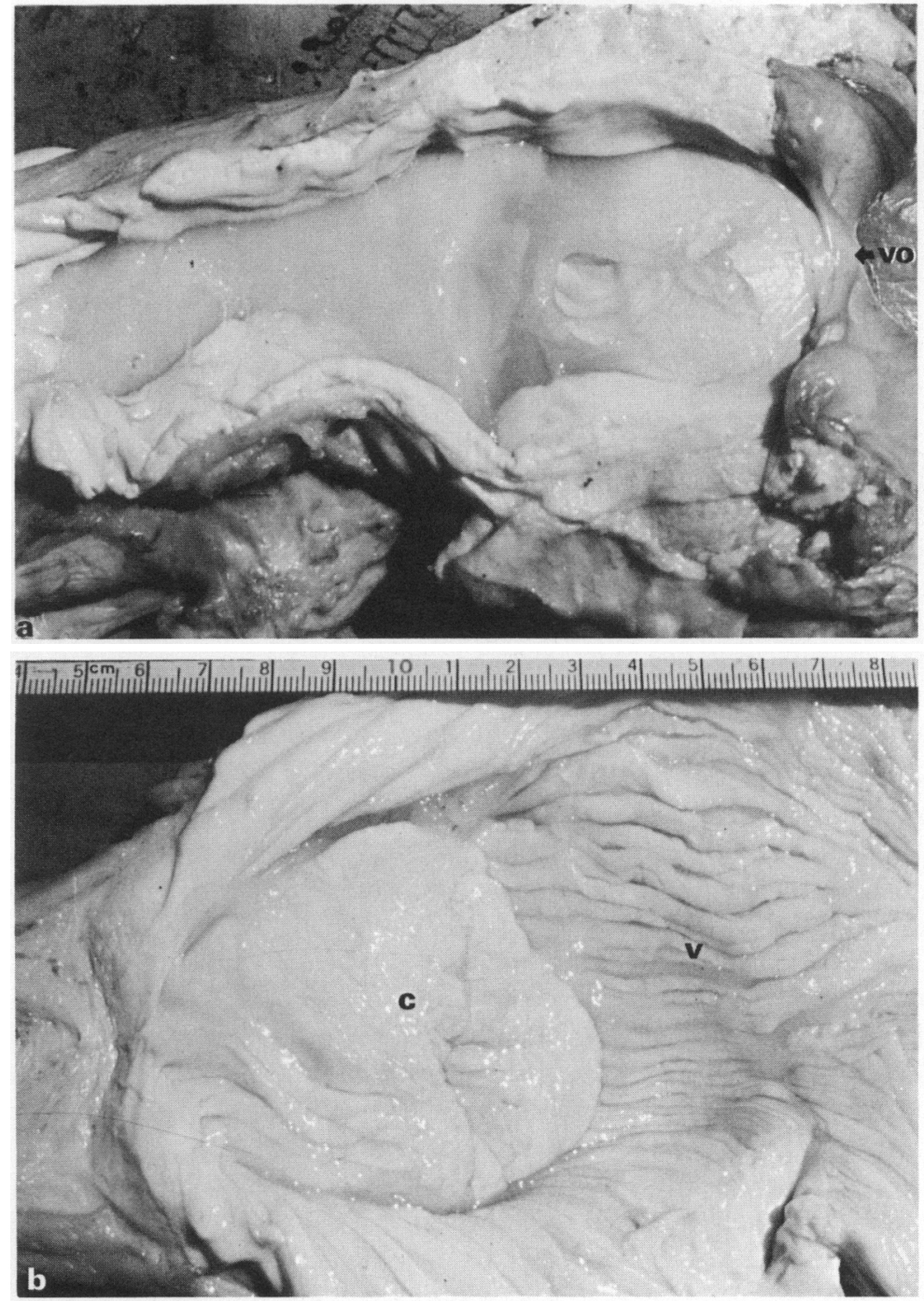

Fig. 4. Vagina and cervix. (a) Mucus within the vagina: vo, vaginal orifice. (b) Cervix: c, cervix; $\mathrm{v}$, vagina.

orifice (hymen) was clearly distinguished in 11 animals. A spongy papilla projecting above the surface of the urogenital canal was felt in the area of the urethral orifice in all elephants. On dissection, the vaginal orifice in all of the elephants was located within the pelvis, $2-10 \mathrm{~cm}$ proximal to the urethral orifice. The urethra opened as a small muscular structure $1-3.8 \mathrm{~cm}$ in diameter (Figs $1 \& 2$ ). It was surrounded by a muscular sphincter which projected into the urogenital canal lumen.

The elephants were classified into two groups on the basis of the characteristics of the vaginal orifice. A wide vaginal orifice $(5-19 \mathrm{~cm})$ was observed in 13 elephants, 13-53 years of age (Fig. 1). The opening in this group of 13 elephants consisted of two large folds of mucous membrane with ragged edges projecting distally into the urogenital canal: 7 of these elephants were pregnant and the uteri of the non-pregnant elephants contained 2-8 placental scars. In a second group of 17 elephants 5-14 years, the vaginal orifice (central orifice in the hymen) was a small round opening of $<2 \mathrm{~cm}$ in diameter (Fig. 2): 4 of these young elephants were pregnant and none of the other 13 non-pregnant uteri contained placental scars. The opening to the vagina of 14 of the animals in the 


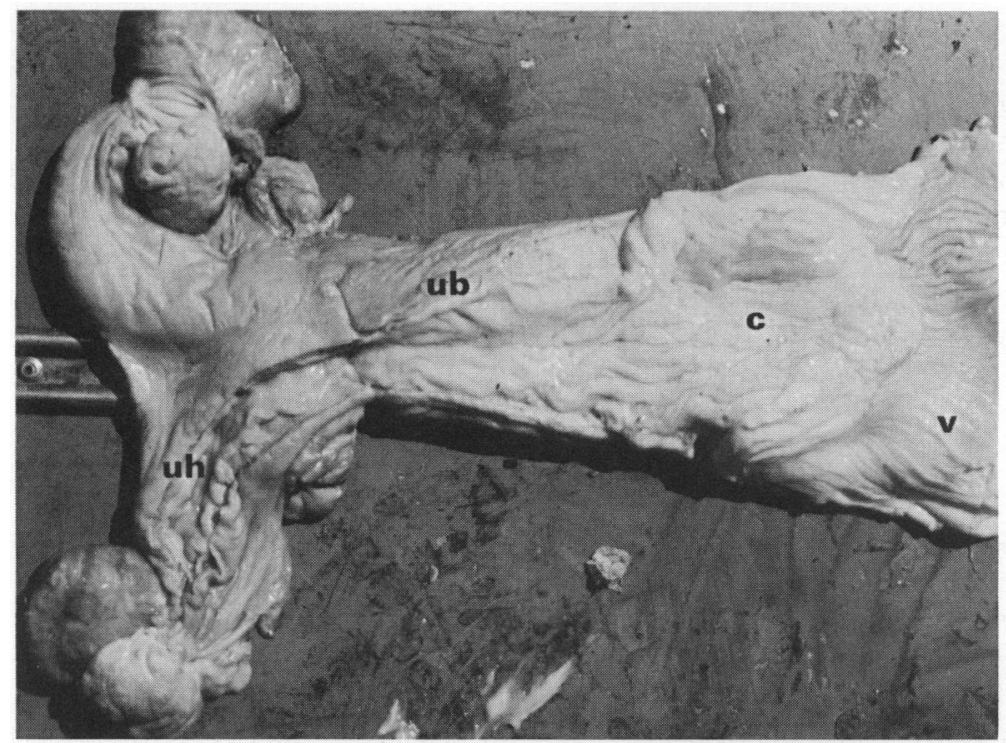

Fig. 5. Uterus, reproductive tract opened: uh, uterine horn; ub, uterine body; c, cervix; v, vagina.

second group was situated between two equally small openings that led into 1-2-cm-long blind canals. In the remaining 3 young elephants, there were slight variations, including additional bands of tissue across the openings (Fig. 3).

The lumen of the vagina, cervix and uterine body contained a variable amount of mucus (Fig. 4a). The mucus adjacent to the vaginal orifice was pale brown and the colour changed rapidly to translucent in the rest of the tract. The vaginal mucous membrane was thrown into a dense array of longitudinal rugae (Fig. 4b). Dye was present in the vagina of 3 non-pregnant elephants where the passage of the tube was assisted by manual palpation ( 2 nulliparous and 1 multiparous). In all of the other elephants the dye was found only in the urogenital canal.

The cervix appeared to be a fold of the inner surface of the reproductive tract (Fig. 4b). This bud-like projection, $2-10 \mathrm{~cm}$ long, was directed towards the vagina, and the surface was composed of longitudinal rugae similar to those of the vagina. The cervical lumen was tightly sealed with mucus and the distal edge of the cervical fold was lobular. The mucous membrane of the uterine body segments of the non-pregnant elephants was also corrugated with longitudinal rugae. These plica extended part way into the uterine horns (Fig. 5).

\section{Discussion}

The most significant finding from this study was the observation of a hymenal membrane in the reproductive tract of nulliparous and primigravid elephants from a naturally reproducing population. In these animals, there was a constriction of the urogenital canal at the entrance to the vagina, just proximal to the urethral orifice. A similar constriction has been described by previous authors but its anatomical significance was unknown (Stukeley, 1723; Hunter, 1861; Miall \& Greenwood, 1878; Forbes, 1879; Chapman, 1880; Watson, 1883; Paterson \& Dun, 1897; Hashimoto et al., 1956; Ruedi et al., 1983). Perry $(1953,1963)$ suggested that the presence of this membrane in mature captive elephants was due to retarded development. However, in the present 13 multiparous elephants examined, it appears that this hymen is torn during parturition, leaving a wide orifice surrounded by ragged folds of mucous membrane. 
The presence of an intact hymen in a pregnant elephant can be used to determine the age at first conception. Examining this area in dead elephants is a simple task, as it is easily exposed during removal of the elephant hide. In a non-pregnant female, an intact hymen $(<5 \mathrm{~cm}$ across all of the multiple openings of the vaginal orifice) indicates a juvenile or infertile elephant. A pregnant elephant with a hymen would be primigravid. The length of gestation can be calculated from the fetal weight (Craig, 1984) and subtracted from the age of the primigravid elephant to give the age at conception. The ages of these animals, combined with those calculated from ovarian and placental scar information, can be used to estimate the age of first reproduction in a population (Laws, 1967; Sherry, 1975). The average age at first conception of 4 primigravid animals in this study was 12 years $(10,12,13$ and 14 years). This is similar to the results from corpora lutea and placental scar data in a 1971-72 study in Gonarezhou, for which the mean age at first ovulation was 12.4 years (range 10-17 years; Sherry, 1975).

The site of ejaculation during natural mating in 4 primigravid elephants was in the urogenital canal. The hymenal constriction was intact and, therefore, during intromission the penis did not penetrate beyond this level. The observation of a $30-\mathrm{cm}$ penetration distance in Asian elephants is also indicative of urogenital tract ejaculation in this species (Eisenberg et al., 1971). Spermatozoa from natural matings are therefore capable of fertilization after travelling the entire length of the reproductive tract from the urogenital canal.

Possible sites for sperm deposition during Al in elephants include (1) the urogenital canal, (2) the vagina and the (3) the cervix or uterus. The urogenital canal is the most accessible site for AI and appears to be the site of ejaculation during natural mating. However, the volume of the natural ejaculate and the mechanical action of the penis would be difficult to duplicate with AI.

The injection of dye into the vagina (simulation of AI), following manual insertion of a catheter, was accomplished in 3 elephants in this study. With the elephants lying on their sides, it was not possible to insert a catheter blindly beyond the urogenital canal. The success of the catheterization procedure was limited by the time allowed, the length of the urogenital canal and the size of the hymen. Palpation of the correct opening in the hymen and insertion of a catheter would not be possible if the urogenital canal was longer than $100 \mathrm{~cm}$. For the elephants in this study, the insemination catheter would have to be $80-140 \mathrm{~cm}$ long to reach the vagina and would have to have a diameter of $<1 \mathrm{~cm}$ to penetrate the hymen of some nulliparous animals. During the non-breeding season, when these elephants were killed, an additional obstacle was the mucus in the vaginal cavity. However, a mucous discharge during the time of receptivity of the female elephant (Eisenberg et al., 1971) may result in clearing of the reproductive tract.

The cervix or uterus is perhaps the best site for AI. Conception rates in domestic cattle are improved if fresh semen is deposited into the cervix rather than the vagina (Lasley \& Bogart, 1943). In the elephant, transcervical AI may be hard to achieve. The elephant cervices observed in this study were flaccid and would be difficult to penetrate. Short (1966) remarked that the lumen of the reproductive tract of a single elephant, shot at the time of oestrus, was larger than that of anoestrous elephants and so the cervix may be more open at this time. The success of the use of any of these sites remains to be determined. Insemination trials at the different sites and the physiological changes in the reproductive tract during oestrus require further investigation.

We thank the research department and the management units No. 1 and 2 of the Department of National Parks and Wildlife, Zimbabwe, particularly Dr D. Cumming, Mr T. Paulet, Mr M. La Grange, Mr G. Sharp, Mr D. Conybeare; and the contracting company, African Genesis Private Limited, especially Mr C. L. Holden and Mr J. F. Honywill, for their co-operation and support in Zimbabwe. We also thank Mr C. H. Hoessle, Mr B. W. Read and Dr K. Mehren for zoological support; Mr T. Boyd for reference material; Mr B. Beck for driving; and Ms J. Graham for assistance with the manuscript. Funding for the project was provided by the Nixon Griffis Fund for Zoological Research, the St. Louis Zoological Park, Fun Safaris, the family of Mr and Mrs M. Basel, and the Research Board, University of Zimbabwe. 


\section{References}

Balke, J.M.E., Read, B.W., Boever, W.J., Gibson, D., Miller, R.E., Junge, R.E., Seal, U.S. \& Plotka, E.D. (1987) Artificial insemination in elephants. Proc. Am. Assoc. Zool. Parks Aquar. Reg. Conf. 652-658.

Balke, J.M.E., Barker, I.K., Hackenberger, M.K., McManamon, R. \& Boever, W.J. (1988) Reproductive anatomy of three female nulliparous Asian elephants: the development of artificial breeding techniques. Zoo Biol. 1, 99-113.

Buss, I.O. \& Smith, N.S. (1966) Observations on reproduction and breeding behaviour of the African elephant. J. Wildl. Mgmt 30, 375-388.

Chapman, H.C. (1880) The placenta and generative apparatus of the elephant. J. Acad. Nat. Sci. Phil. (series 2) 8, 413-422.

Craig, G.C. (1984) Foetal mass and date of conception in African elephants: a revised formula. S. Afr. J. Sci. 80, 512-516.

Eisenberg, J.F., McKay, G.M. \& Jainudeen, M.R. (1971) Reproductive behaviour of the Asiatic elephant (Elephas maximus maximus L). Behaviour 38, 193-217.

Forbes, W.A. (1879) On the anatomy of the African elephant, Elephas africanus. Proc. zool. Soc. Lond. 420-435.

Hashimoto, Y., Yamauchi, S. \& Yasunobo, E. (1956) Dissection of an elephant. Bull. Univ. Osaka Prefec. (series B) 6, 30-52.

Hunter, J. (1861) Observations on comparative anatomy, order Proboscidia, the elephant (Elaphus Indicus). In Essays and Observations, 2, 170-176. Ed. R. Owen. Van Voorst, London.

Lang, E.M. (1980) Observations on growth and molar change in the African elephant. Afr. J. Ecol. 18, 217-234.

Lasley, J.F. \& Bogart, R. (1943) Some factors influencing reproduction efficiency of range cattle under artificial and natural breeding conditions. Res. Bull. Mo. Agric. Exp. Stn 376, 3-56.

Laws, R.M. (1967) Occurrence of placental scars in the uterus of the African elephant (Loxodonta africana). J. Reprod. Fert. 14, 445449.

Miall, L.C. \& Greenwood, F. (1878) The anatomy of the Indian elephant. Part III. J. Anat. Physiol. 13, 17-50.

Nevill, G.F., Crompton, W.G., Hennessy, M.A. \& Watson, P.F. (1976) Instrumentation for artificial insemination in the African elephant Loxodonta africana. Int. Zoo Ybk 16, 166-171.
Paterson, A.M. \& Dun, R.C. (1897) The genito-urinary organs of the female Indian elephant. J. Anat. Physiol. 32, 582-604.

Perry, J.S. (1953) The reproduction of the African elephant, Loxodonta africana. Phil. Trans. R. Soc. Ser. $B$ 237, 93-149.

Perry, J.S. (1964) The structure and development of the reproductive organs of the female African elephant. Phil. Trans. R. Soc. Ser. B 248, 35 -51.

Plotka, E.D., Seal, U.S., Zarembka, F.R., Simmons, L.G., Teare, A., Phillips, G., Hinshaw, K.C. \& Wood, D.G. (1988) Ovarian function in the elephant: luteinizing hormone and progesterone cycles in African and Asian elephants. Biol. Reprod. 38, 309-314.

Price, P., Bradford, J. \& Schmitt, D. (1986) Collection and semen analysis in Asian elephant. Proc. Am. Assoc. Zool. Parks Aquar. 310-313.

Ruedi, D. \& Kuepfer, U. (1981) Semen collection in the African elephant (Loxodonta africana): a step towards artificial insemination. Proc. Am. Assoc. Zoo Vet. 142-143.

Ruedi, D., Kuepfer, U., Girard, J. \& Gutzwiller, A. (1983) Untersuchungen zur fortflanzungsphysiologie biem Afrikanischen elefanten (Loxondonta africana): Samengewihhung bei wildbullen, anatomiestudien an wildkuhen, weitere schritte hinsichtlich kunstlicher besamung. Verhandlungsbericht 25 Int. Sym. Erkranlungen Zootiere Wein, 341-348.

Schmidt, M. (1982) Studies on Asian elephant reproduction at the Washington Park Zoo. Zoo Biol. 1, 141-147.

Sherry, B.Y. (1975) Reproduction of elephant in Gonarezhou, South-eastern Rhodesia. Arnoldia 7, $1-13$.

Short, R.V. (1966) Oestrous behaviour, ovulation and the formation of the corpus luteum in the African elephant, Loxodonta africana. E. Afr. Wildl. J. 4, 56-68.

Stukeley, W. (1723) Of the Spleen, Its Description and History to which is added some Anatomical Observations in the Dissection of an Elephant. The author, London.

Watson, M. (1883) Additional observations on the structure of the female organs of the Indian elephant (Elephas indicus). Proc. zool. Soc. Lond. 517-521.

Received 17 February 1988 